\title{
Reversible Inhibition of Movement in the Amoebae Dictyostelium discoideum and its Effect on Chemoattractant Recognition*
}

\author{
Agnieszka WALIGÓRSKA, Magdalena WiAnECKA-SKOCZEŃ, and Włodzimierz KOROHODA
}

\begin{abstract}
WALIGÓRSKA A., WianeCKA-SKOCZEŃ M., KOROHODA W. 2008. Reversible inhibition of movement in the amoebae Dictyostelium discoideum and its effect on chemoattractant recognition. Folia biol. (Kraków) 56: 123-131.

The cell fixatives formaldehyde and $\mathrm{KMnO}_{4}$ at low concentrations reversibly inhibit the movement of $D$. discoideum amoebae without directly interfering with cell viability. This inhibition of cell movement is accompanied by the decreased attachment of cells to substratum. When the tenacity and attachment of immobilized cells are artificially increased by compressing cells between two glass surfaces, the amoebae begin to move even in the presence of the fixatives. Amoebae starved for 24 hours, subjected to fixatives and a mineral salt solution in which they remained motionless, maintained chemotactic responses to folic acid and only after a few hours of active locomotion became reactive to cAMP, in contrast to amoebae that reacted to cAMP after starvation in the absence of fixatives.
\end{abstract}

Key words: Cell movement, Dictyostelium discoideum, chemotaxis, folic acid, cAMP, movement inhibition, cell membrane, fixatives

Agnieszka WALIGÓRSKA, Magdalena WIANECKA-SKOCZEŃ, Wtodzimierz KOROHODA, Department of Cell Biology, Faculty of Biochemistry, Biophysics and Biotechnology, Jagiellonian University, Gronostajowa 7, 30-387 Kraków, Poland.

E-mail:korohoda@mol.uj.edu.pl

A b b r e vi a ti o n s: D. discoideum - Dictyostelium discoideum, FA - folic acid

The importance of cell movement during embryogenesis, regeneration, immune response, spread of cancer cells and formation of metastases is commonly appreciated and studied in many laboratories. Nevertheless, there remain some unanswered questions. One is how originally motionless cells commence motile activity, leave their local environment and upon reaching their destination stop moving and remain motionless (ABERCROMBIE \& AMBROSE 1962; WILKINSON 1987; VON TSCHARNER BIINO et al. 1997). The analysis of cell movement when studied in vivo and in vitro is often difficult because movement is not continuous. Such behaviour has been described by many studies for various cells both in vivo and in vitro (WILKINSON 1987; POMORSKI et al. 2004; REICHMAN-FRIED et al. 2004).

Cell mobilization has been studied especially in relation to the mechanisms of contact inhibition, scatter factors, cytokines, proteolytic enzymes, chemotaxis and galvanotaxis, all of which have gained the attention of many investigators; however, less attention has been paid to factors which immobilize cells (ABERCROMBIE \& AMBROSE 1962; JACOBELLI et al. 2004; TAMAGNONE \& COMOGLIO 2004). The formation and maturation of focal contacts (WÓJCIAK-STOTHARD et al. 1997), gap junctions and desmosomes occur later, when cells are already immobilized. In addition reversible prevention of movement, without interfering with cell viability, would have many advantages for experimentalists.

There have been various experimental attempts to reversibly inhibit cell movement, including decreasing temperature, applying viscous media (polyvinyl alcohol, methylcellulose solutions), and cell detachment or cell seeding on non-adhesive substrata (SAYERS et al. 1979; JOUNG et al. 1987; HASSLEN et al. 1996). In this report we describe how modification of the cell membrane is used to reversibly inhibit cell movement. This was achieved by modification of the cell membrane of $D$. discoideum amoebae using fixatives at low concentra- 
tions, without direct impairment of intracellular processes. The investigations were carried out on D. discoideum amoebae, although similar qualitative observations have been made on other motile cells.

The second question we addressed concerns the capacity of $D$. discoideum amoebae to change their chemotactic response during starvation. Well fed amoebae respond to folic acid (FA) and pterines, whereas after starvation in mineral salt solutions for 6 or more hours they begin to produce and react to cAMP (KESBEKE et al. 1990; MILNE \& COUKELL 1991; REYMOND et al. 1995; NEBL \& FISHER 1997; ARKOWITZ 1999; KOROHODA et al. 2002). As we report in this communication, starved and immotile amoebae maintain the capacity to recognize and respond to FA for at least $24 \mathrm{~h}$ and require the next several hours of starvation before they become sensitive to cAMP.

\section{Material and Methods}

\section{Cell Culture}

Dictyostelium discoideum strain AX-2 (ATCC24397) was cultured as described previously (KOROHODA et al. 2002; SROKA et al. 2002) in medium containing: $14.3 \mathrm{~g} / 1$ meat peptic peptone (Oxoid Ltd, England), $7.15 \mathrm{~g} / 1$ yeast extract (BioMerieux, France), $18 \mathrm{~g} / 1$ maltose (Sigma St. Louis, MO), $1.28 \mathrm{~g} / 1$ $\mathrm{Na}_{2} \mathrm{HPO}_{4} \times 12 \mathrm{H}_{2} \mathrm{O}, 0.48 \mathrm{~g} / 1 \mathrm{KH}_{2} \mathrm{PO}_{4}$, adjusted to $\mathrm{pH}$ 7.4. The cells were grown in suspension at $20^{\circ} \mathrm{C}$, harvested at the exponential growth stage, washed three times with Chalkley's solution $(14 \mathrm{mM} \mathrm{NaCl}$, $0.27 \mathrm{mM} \mathrm{KCl}, 0.5 \mathrm{mM} \mathrm{CaCl} 2,0.5 \mathrm{mM} \mathrm{MgCl}_{2}$ ), resuspended in Chalkley's medium and plated in Petri dishes. For chemotaxis studies the cells were starved in Chalkley's medium for $6 \mathrm{~h}$ at $20^{\circ} \mathrm{C}$, resuspended in fresh medium and plated into a special chemotactic chamber described previously (KOROHODA et al. 1997; KOROHODA et al. 2002), in order to observe the effects of folic acid (FA) and cAMP.

\section{Recording of cell motility}

Cell migration was observed with an inverted Hund Wilovert S microscope, recorded with a Hitachi CCD camera, digitized and processed with programs written by P. Jochym and R. Tokarski. Images were recorded every $60 \mathrm{~s}$ and each cell was contoured at $\mathrm{t}_{0}$ and after $60 \mathrm{~min}$.

Cells were considered migrating if their projections after 60 minutes did not share any area with their projections at $t_{0}$.

The trajectories of migrating cells were determined by images taken every $30 \mathrm{~s}$ for $20 \mathrm{~min}$. Tracks of individual cells were generated by the cell's centroid position in each frame, with whole trajectories which were composed of 40 consecutive centroid displacements. The program Mathematica was used for further data processing. Cell trajectories are presented as circular diagrams with the starting point of each trajectory located in the centre of the diagram.

\section{Inhibition of cellular motility}

Adherent cells in Chalkley's solution were treated with various concentrations of formaldehyde or potassium permanganate. Cell movement in diluted fixative solutions was recorded for 90 min. with images acquired every 60 seconds. Each recorded cell was contoured after $30 \mathrm{~min}$. and again after a further $30 \mathrm{~min}$. of incubation. The percentage of migrating cells was determined.

\section{Viability test}

Cells of $D$. discoideum were incubated in the presence of various concentrations of formaldehyde or potassium permanganate for $24 \mathrm{~h}$, and suspensions of cells were mixed with fluorescein diacetate and ethidium bromide solution (DANKBERG \& PERSIDSKY 1976; SZYDŁOWSKA et al. 1978). The results represent the mean values of three measurements obtained from three independent experiments in which 200 cells were observed in each.

\section{Reversibility of cellular motility inhibition}

Cells of $D$. discoideum were incubated in the presence of formaldehyde solutions for $24 \mathrm{~h}$, then shaken on a rotary shaker, resuspended in fresh Chalkley's solution, plated in a Petri dish and recorded for $180 \mathrm{~min}$ as described above. The percentage of migrating cells was determined $180 \mathrm{~min}$ after removal of formaldehyde.

"Chimneying effect" - the ability of $D$. discoideum amoebae to regain migration capability in fixative solutions under a coverslip

Adherent amoebae of $D$. discoideum cells were treated with $0.8 \mathrm{mM}$ formaldehyde or $0.05 \mathrm{mM}$ potassium permanganate in Chalkley's medium. After $30 \mathrm{~min}$. of incubation, when locomotion of the cells had completely ceased, a coverslip was put into the Petri dish to gently cover the cells and the medium was removed beneath the level of the upper surface of the coverslip (KELLER \& ZIMMERMANN 1985; KELLER et al. 1989, 2002; MALAWISTA \& DE BOISFLEURY CHEVANCE 1997; MALAWISTA et al. 2000, 2002). After 180 min cell locomotion was recorded for $20 \mathrm{~min}$ at time intervals of $30 \mathrm{~s}$. 
A

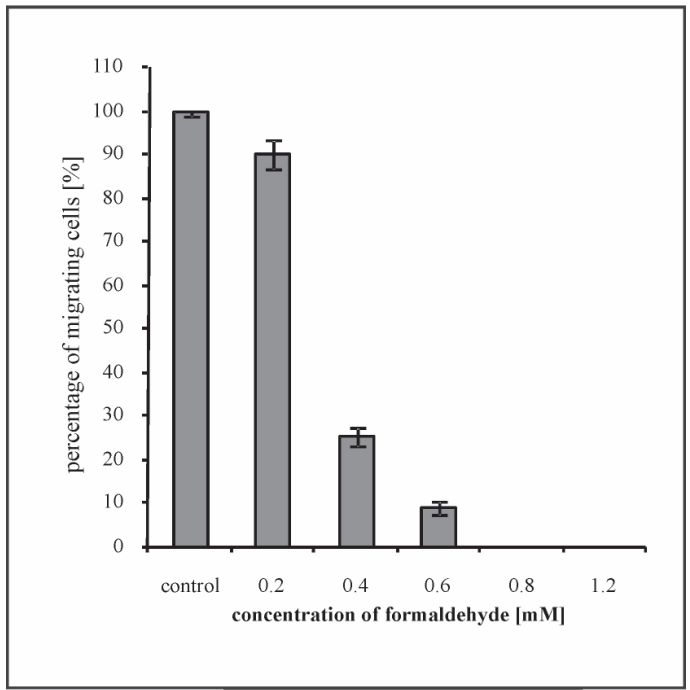

B

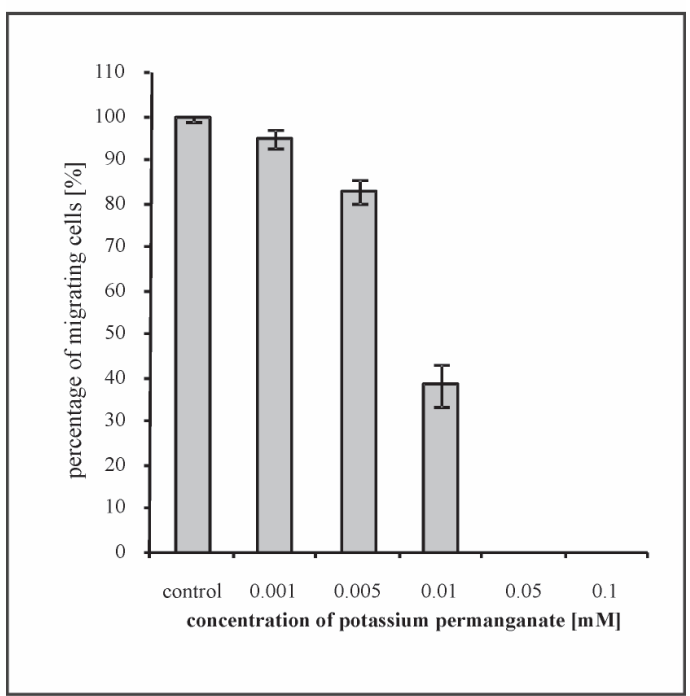

Fig. 1. Percentage of moving amoebae incubated for 0.5 hour in various concentrations of formaldehyde (A) and potassium permanganate (B) in Chalkley's medium.

\section{Cell migration in response to chemoattractants}

Migration of cells in developing concentration gradients of folic acid (FA) and cAMP was observed in a chemotactic pocket-like chamber, as previously described (KOROHODA et al. 1997; KOROHODA et al. 2002). The effects of folic acid $(0.5 \mathrm{mM})$ or cAMP $(1 \mu \mathrm{M}))$, both in Chalkley's medium, were examined (i) in cells taken directly from the growth medium (Fig. 3A, B), (ii) in cells starved in mineral salt solutions for $24 \mathrm{~h}$ (Fig. $3 \mathrm{C}$, D), (iii) in cells starved in mineral salt solutions in the presence of diluted fixatives added directly after washing out fixatives (Fig. 3 E, F) and (iv) $6 \mathrm{~h}$ later when these cells were permitted to move actively without fixatives (Fig. $3 \mathrm{G}, \mathrm{H}$ ).

\section{Results}

Cell fixatives are commonly used to kill cells and to stabilize their structures for light or electron microscopy. Formaldehyde and potassium permanganate are often used for fixation of cells in light microscopy and electron microscopy, respectively. Formaldehyde is known to stabilize cell membranes without affecting their immunological and electrochemical properties, and potassium permanganate is often used for fixation of membranous structures (SEAMAN \& COOK 1965; GINGELL \& TODD 1975; HANNIG et al. 1990). Formaldehyde and glutaraldehyde stabilize both natural biological membranes and black lipid membranes or liposomes, and modify ion fluxes across membranes. At low concentrations these fixatives do not kill the cells but modify their membranes (PRZESTALSKI et al. 1978; HASSLEN et al. 1996; JOVTCHEV et al. 2000).

In the first experiments we estimated nonlethal concentrations of these two fixatives, permitting

Table 1

Effect of formaldehyde diluted in Chalkley's medium on viability and locomotion of D. discoideum amoebae

\begin{tabular}{||l|c|c|c|c|c|c||}
\hline \multirow{2}{*}{} & \multicolumn{6}{|c||}{ Concentration of formaldehyde } \\
\cline { 2 - 7 } & $0 \mathrm{mM}$ & $0.2 \mathrm{mM}$ & $0.4 \mathrm{mM}$ & $0.6 \mathrm{mM}$ & $0.8 \mathrm{mM}$ & $1.2 \mathrm{mM}$ \\
\hline $\begin{array}{l}\text { Viability of cells incubated for 24 hours } \\
\text { in the presence of formaldehyde as esti- } \\
\text { mated with the cell viability test }\end{array}$ & $97.73 \pm 0.93$ & $97.65 \pm 0.38$ & $93.44 \pm 3.77$ & $88.56 \pm 6.65$ & $87.96 \pm 8.19$ & $75.49 \pm 8.52$ \\
$\begin{array}{l}\text { Percentage of cells migrating after 30 min } \\
\text { incubation in the presence of formalde- } \\
\text { hyde }\end{array}$ & $99.33 \pm 0.67$ & $89.88 \pm 3.28$ & $25.04 \pm 2.19$ & $8.97 \pm 1.54$ & 0 & 0 \\
$\begin{array}{l}\text { Percentage of cells migrating 3h after re- } \\
\text { moval of formaldehyde, in the presence of } \\
\text { which the cells were preincubated for 24h }\end{array}$ & $94.07 \pm 2.68$ & $92.14 \pm 2.98$ & $86.02 \pm 4.19$ & $82.52 \pm 10.02$ & $63.00 \pm 5.00$ & $41.81 \pm 11.11$ \\
\hline
\end{tabular}




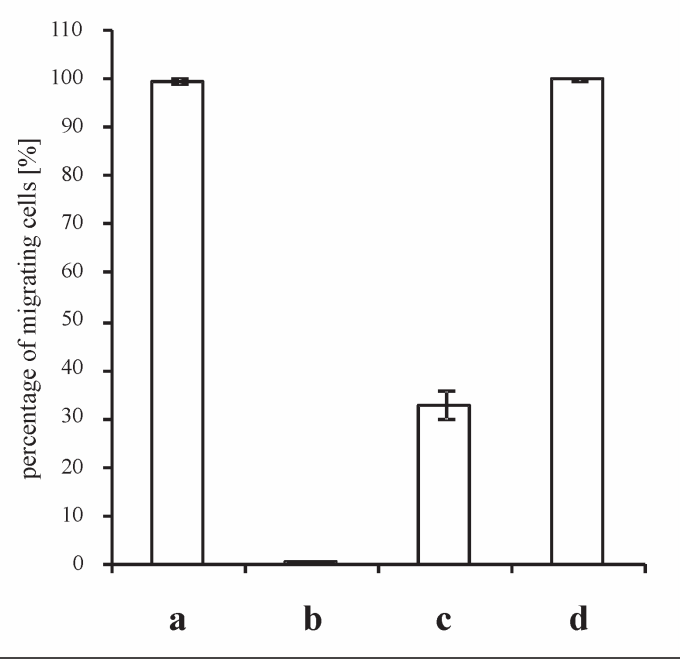

Fig. 2. The percentage amoebae moving: a - under control conditions (in Chalkley's medium), $\mathrm{b}-$ in the presence of $0.8 \mathrm{mM}$ formaldehyde in bulk solution, $\mathrm{c}-$ in the presence of $0.8 \mathrm{mM}$ formaldehyde, 2 hours under the coverslip, $\mathrm{d}-$ in the presence of $0.8 \mathrm{mM}$ formaldehyde, 3 hours under the coverslip.

A

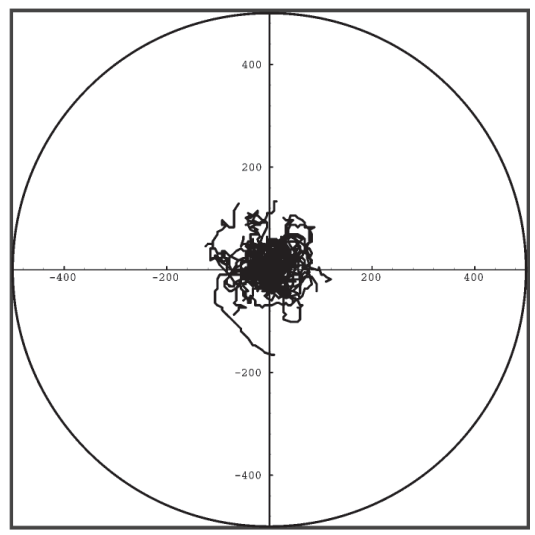

C

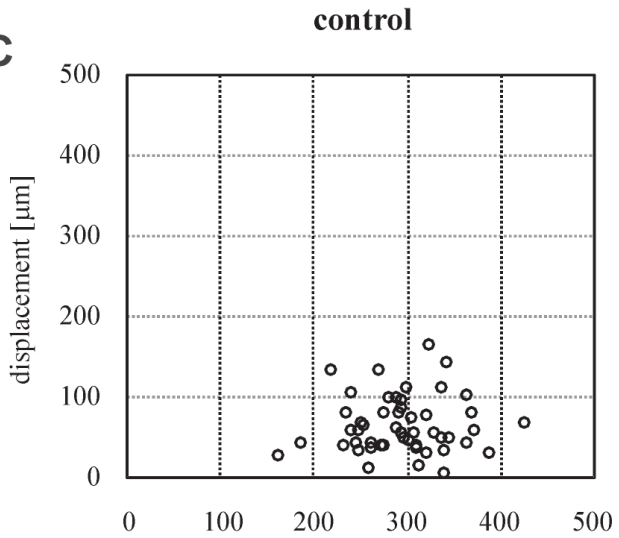

total length of cell trajectory [ $\mu \mathrm{m}]$ the treated $D$. discoideum cells to recover after prolonged treatment.

Figure 1A shows the percentage of amoebae moving after remaining for 0.5 hour in solutions containing various concentrations of formaldehyde. The $0.8 \mathrm{mM}$ concentration of formaldehyde fully inhibited cell movement within 30 minutes (Fig. 1A). When cells were incubated for 24 hours in this solution they assumed a spherical shape and remained motionless, but nevertheless, they accumulated neutral red (data not shown) which is often used as an indicator of cell viability (LASAROW et al. 1992). $\mathrm{KMn}_{4}$ solutions in Chalkley's medium showed that $0.05 \mathrm{mM}$ potassium permanganate achieved similar immobilization (Fig. 1B).

In Table 1 the effects of incubation of $D$. discoideum cells in solutions of $0.2 \mathrm{mM}$ to $1.2 \mathrm{mM}$ formaldehyde in Chalkley's solution for 24 hours are shown. The cells survived after 24 hours (or even 48 , data not shown) of incubation in the presence of $0.8 \mathrm{mM}$ formaldehyde. After removal of formaldehyde and washing, more than $60 \%$ of the cells resumed locomotion within 3 hours (Table 1).

B
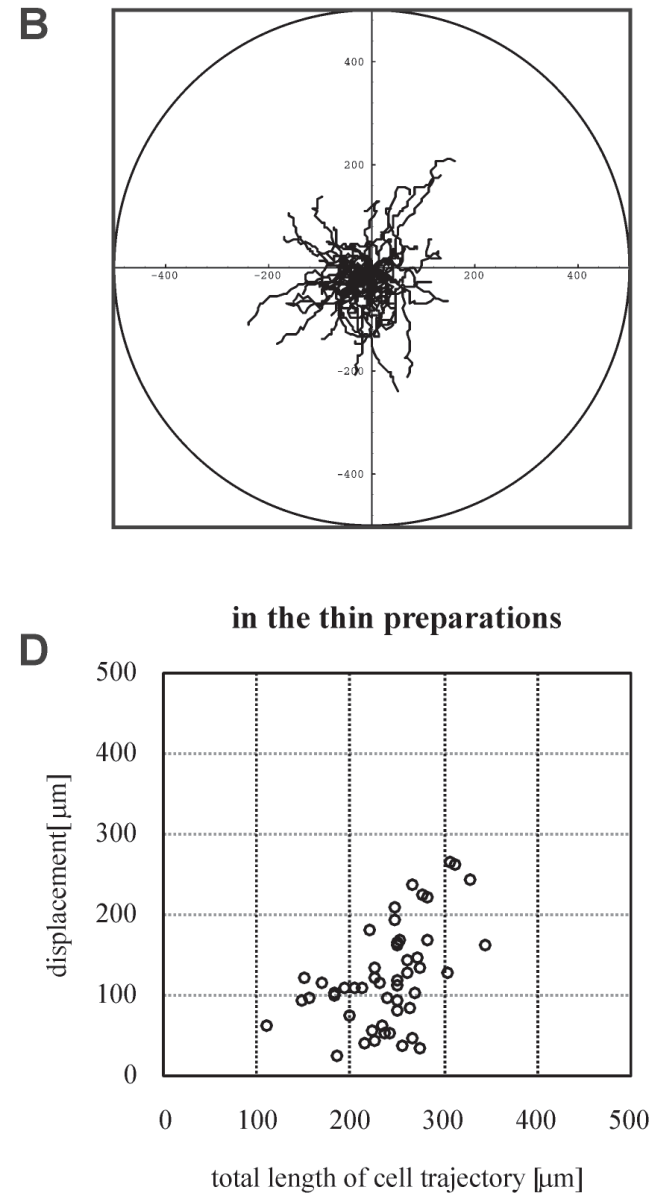

Fig. 3. A, B - Circular diagrams of cell trajectories for $D$. discoideum amoebae $(n=50)$ moving in control isotropic conditions in the absence of fixatives (A) and in the thin preparations in the presence of $0.8 \mathrm{mM}$ formaldehyde. C, D - Scatter correlation diagrams of total length of cell trajectories and displacements of $D$. discoideum cells migrating in control conditions $(\mathrm{C})$ and in the thin preparations in the presence of $0.8 \mathrm{mM}$ formaldehyde (D) (corresponding correlation coefficients were 0.05 for $\mathrm{C}$ and 0.50 for D). 

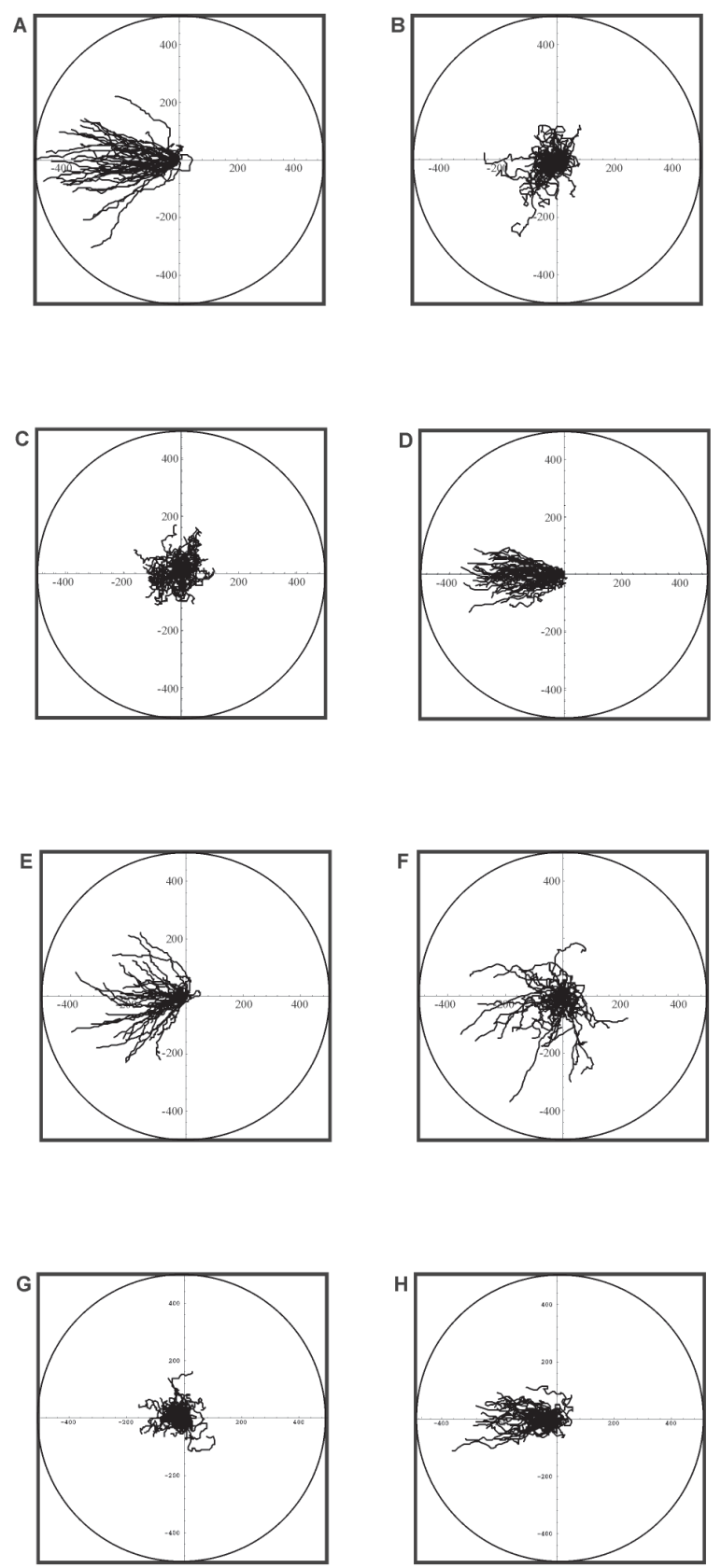

Fig. 4. The effects of folic acid $(0.5 \mathrm{mM})(\mathrm{A}, \mathrm{C}, \mathrm{E}, \mathrm{G})$ or cAMP (1M) (B, D, F, H), both in Chalkley's medium on cells directly taken from the growth medium (A, B), on cells which were starved in Chalkley's mineral salt solutions for $24 \mathrm{~h}$ (C, D), on cells which were starved in Chalkley's solutions in the presence of diluted $0.8 \mathrm{mM}$ formaldehyde, directly after washing out the formaldehyde (E, F) and $6 \mathrm{~h}$ later when these cells were permitted to move actively without formaldehyde $(G, H)$. Number of cells in each experiment, $\mathrm{n}=50$.

Similar experiments have shown that cells incubated for 24 hours in $0.05 \mathrm{mM}$ potassium permanganate and Chalkley's solution survived for 24 hours. Three hours after washing $77 \%$ of cells resumed locomotion. Therefore the concentrations $0.8 \mathrm{mM}$ of formaldehyde and $0.05 \mathrm{mM}$ potassium permanganate were chosen for further experiments.
Cells treated with fixatives assumed a spherical shape and became detached from the substratum, freely floating within the medium. To examine whether the fixatives disturb and directly influence intracellular structures and their activity, or act primarily upon cell membranes, we performed experiments in which cell attachment to glass was artificially constrained (forced) by compressing the cells between two glass surfaces in a narrow chamber (KELLER \& ZIMMERMANN 1985; KELLER et al. 1989, 2002; MALAWISTA \& DE BOISFLEURY CHEVANCE 1997; MALAWISTA et al. 2000, 2002). Under such conditions $100 \%$ of the $D$. discoideum amoebae resumed locomotion within 3 hours in spite of the continuous presence of $0.8 \mathrm{mM}$ formaldehyde or $0.05 \mathrm{mM}$ potassium permanganate in Chalkley's solution. The cells artificially compressed in the presence of diluted fixatives moved along more straight trajectories than control cells under isotropic conditions (Fig. 3). By contrast, non-compressed cells in these solutions remained fully motionless (Fig. 2).

Amoebae incubated in the presence of formaldehyde or potassium permanganate, either in suspension or weakly attached to a glass surface, remained fully motionless for 24 hours. Unstarved amoebae taken from growth medium reacted chemotactively to folic acid but did not react to cAMP (Fig. 4A, B). After starvation in mineral salt solution for 6 or 24 hours the amoebae became sensitive to cAMP and did not react to folic acid (Fig. $4 \mathrm{C}, \mathrm{D})$. In contrast, amoebae starved for 24 hours in the solution supplemented with diluted fixatives maintained chemotactic responses to FA and did not react to cAMP (Fig. 4E, F). These cells required several hours after removal of fixatives to start reacting to cAMP (Fig. 4G, H). Similar behaviour of $D$. discoideum amoebae was observed after incubation in the presence of diluted potassium permanganate.

\section{Discussion}

In recent years research on cell motility has mainly concentrated on the molecular mechanisms operating in signaling pathways and on mechanochemical processes occurring in the cytoskeleton and on the specific proteins involved (KESBEKE et al. 1990; JACOBELLI et al. 2004). The extracellular factors which influence cell motile responses have received relatively little study. This communication has examined the induction of signaling pathways which influence the reception and selection of specific and non-specific extracellular signals.

Spontaneous cell movement takes place in the absence of any particular stimulus from the environment, whereas directed cell movements occur 
in response to environmental stimuli. They depend upon the sensitivity of specialized receptors in cell membranes corresponding to sense organs in metazoan organisms. It is commonly recognized that the specific receptors and ion channels localized in cell membranes play a decisive role in the direction of cell movement (NEBL \& FISHER 1997; SALLUSTO et al. 1998; ARKOWITZ 1999; KRISHNAN $\&$ IGLESIAS 2004). The general properties of lipid bilayers and protein-lipid interactions, modified by the cell fixatives formaldehyde and potassium permanganate, have strongly suggested that cell surface dynamic properties are instrumental in the process of cell motility. Thus, inhibition of cell movement was achieved with cell fixatives, which rather nonspecifically and in different ways stabilize the dynamic properties of the cell membrane. Both fixatives inhibited cell movement reversibly at concentrations which did not significantly influence cell viability. The modification of cell membranes was found to inhibit cell movement, to cause cell rounding and detachment of cell from substrata. In the presence of fixatives, the cells remained viable and accumulated neutral red (cf. LASAROW et al. 1992).

To check whether the fixatives affected primarily the cell membrane or acted directly upon signaling pathways or the actin cytoskeleton, we adapted a method commonly used to study movement of normally non-adherent cells and preventing passive cell translocations. Locomotion of non-adherent cells was studied in narrow slidecoverslip preparations (depth: $5-8 \mu \mathrm{m}$ ) prepared as described by KELLER (KELLER \& ZIMMERMANN 1985, 1986; KELLER et al. 1989, 2002; ZIMMERMANN \& KELLER 1992, 1993; FEDIER \& KELLER 1997; FEDIER et al. 1999; KELLER 2000) and MALAWISTA (MALAWISTA \& DE BOISFleURY CHEVANCE 1997; MALAWISTA et al. 2000, 2002, 2003; MONTGOMERY et al. 2004). The method has been described as locomotion of cells in "thin slide-coverslip preparations" (KELLER \& ZIMMERMANN 1985, 1986; KELLER et al. 1989), in "close quarters" (MALAWISTA et al. 2000) or "chimneying of cells" (MALAWISTA \& DE BOISFLEURY CHEVANCE 1997; MALAWISTA et al. 2000, 2003). Under such conditions artificially attached and compressed cells resumed movement in the presence of fixatives, thereby showing that the fixatives impaired cell movement by acting at the cell membrane rather than upon signaling pathways or the actin cytoskeleton. This suggests that such experiments may be useful for examining whether other specific factors act upon the cell surface or more directly interfere with intracellular processes of other cell systems. Such modulation of cell surface properties for the regulation of cell functions was elegantly demonstrated by BURGER (1971) who has shown that coating of the neoplastic cancer cell surface with monovalent concanavalin A reversibly restored contact inhibition of cell movement and growth. Nevertheless, non-motile cells when compressed in thin preparations did not only resume locomotion in the presence of diluted fixatives but moved along more straight trajectories. For cells moving under such conditions a closer correlation of the final cell displacement and length of cell trajectories was observed than for cells moving under isotropic conditions in thicker preparations. Such scatter correlation diagrams as shown in Fig. 3C, D illustrate the homo/heterogeneity of cell populations and the tendency of cells to translocate along torturous or straight trajectories (cf. WALIGÓRSKA et al. 2007). The observations reported may therefore suggest that cell compression by close approximation of slide and coverslip causes not only better contact of cells with the solid substratum (i.e. the "chimneying" effect discussed by KELLER (KELLER \& ZIMMERMANN 1985; KELLER 2000) and MALAWISTA (MALAWISTA \& DE BOISFLEURY CHEVANCE 1997; MALAWISTA et al. 2000, 2003) but also modifies cell stiffness and tensegrity causing more permanent cell polarization (cf. INGBER \& FOLKMAN 1989; INGBER 2003).

The changes in receptors during cell differentiation occur not only during maturation of $D$. discoideum amoebae, but are often observed during cell differentiation, in immune cell systems during sensitization to specific antigens or under the effect of cytokines (SALLUSTO et al. 1998; SERVANT et al. 1999).

The observations reported here have shown that changes in recognition of specific chemoattractants in $D$. discoideum amoebae require not only cell starvation (TILLINGHAST \& NEWELL 1987; MiLNE \& COUKELL 1991; REYMOND et al. 1995; NEBL \& FISHER 1997), but also cell movement or attachment to solid substratum. This may be a more general phenomenon for other cell types. Cell polarization and shape changes which occur during cell locomotion are accompanied by changes in the location of cell surface components, including receptors (JOHANSSON et al. 1993; SERVANT et al. 1999; PRIGOZHINA \& WATERMAN-STORER 2004). Indeed, in anchorage dependent cells, their attachment to substratum causes cell activation, entrance of cells inhibited in the $\mathrm{G} 1$ phase of the cell cycle to the S phase, stimulation of cell respiration, glycolysis, and fagocytosis (KOROHODA 1972). Such processes apparently depend upon attachment of cells to substratum. initiating signaling pathways, changes in cell shape, growth and differentiation. Similarly, cell movement is reported to influence membrane recycling and the exchange of plasma membranes with intracellular membranes, as postulated for amoebae by PANTIN (1924) and GOLDACRE 
(1964), and for tissue cells by HARRIS (1973) and BRETSCHER (1976, 1996a, 1996b). Quantitative studies with amoebae have shown that this process is slow and requires hours for full recycling of the cell membrane, sufficient for cells to move a distance many times greater than the cell length. In migrating cells, membrane internalization takes place at the cell uroid (in amoebae) (HAUSMANN et al. 1972; HAUSMANN \& STOCKEM 1972; STOCKEM 1972) or in fibroblasts at the tail and perinuclear regions (HARRIS 1973; BRETCHER 1996a). Near the leading fronts of extending surface protrusions, intracellular membranes are incorporated which originate from the internalized cell membrane and from secreting vacuoles formed in Golgi apparatuses (STOCKEM 1972).

The basic mechanism responsible for changes in chemoattractant response by $D$. discoideum amoebae is likely to relate to receptor expression, apparently regulated by cell adhesion and motility, both related to starvation and maturation (VAN HAASTERT \& KIEN 1983; MILNE \& COUKELL 1991; REYMOND et al. 1995; TANAKA et al. 1998). We therefore propose that these observations of changes in the dynamic properties of cell membranes can facilitate further studies on the mechanisms of chemotaxis, and on membrane turn-over and recycling during cell locomotion.

In conclusion the results presented in this communication show that:

i) cells can be reversibly immobilized with diluted fixatives without interfering with cell viability;

ii) cells can be induced to move in the presence of fixatives by an artificial increase of cell attachment and shape changes by gently compressing the cells between glass surfaces;

iii) $D$. discoideum amoebae after starvation in the presence of diluted fixatives on the removal of fixatives continued to respond chemotactively to folic acid and required a further few hours of starvation in the absence of fixatives to become sensitive to cAMP.

\section{Acknowledgements}

The authors cordially thank prof. D. E. WOOLLEY, University of Manchester, UK for valuable discussions and language corrections.

\section{References}

Abercrombie M., Ambrose E. J. 1962. The surface properties of cancer cells: a review. Cancer Res. 22: 525-548.

ARKOWITZ R. A. 1999. Responding to attraction: chemotaxis and chemotropism in Dictyostelium and yeast. Trends Cell Biol. 9: 20-27.
BRETSCHER M. S. 1976. Directed lipid flow in cell membranes. Nature 260: 21-23.

BRETSCHER M. S. 1996a. Moving membrane up to the front of migrating cells. Cell 85: 465-467.

BRETSCHER M. S. 1996b. Getting membrane flow and the cytoskeleton to cooperate in moving cells. Cell 87: 601-606.

BURGER M. M. 1971. The significance of surface structure changes for growth control under crowded conditions. In: Growth Control in Cell Cultures. G. E. W. Wolstenholme \& J. Knight eds, Churchill Livingstone, Edinburgh \& London. Pp. 45-69.

DANKBERG F., PERSIDSKY M. D. 1976. A test of granulocyte membrane integrity and phagocytic function. Cryobiology 13: $430-432$.

Fedier A., EGgl P., Keller H. U. 1999. Redistribution of surface-bound con A is quantitatively related to the movement of cells developing polarity. Cell. Motil. Cytoskeleton 44: 44-57.

FeDier A., Keller H. U. 1997. Suppression of bleb formation, locomotion, and polarity of Walker carcinosarcoma cells by hypertonic media correlates with cell volume reduction but not with changes in the F-actin content. Cell. Motil. Cytoskeleton 37: 326-337.

GingELL D., TODD I. 1975. Adhesion of red blood cells to charged interfaces between immiscible liquids. A new method. J. Cell Sci. 18: 227-239.

GOLDACRE R. J. 1964. On the mechanism and control of ameboid movement. (In: Primitive Motile Systems. N. Kamiya R. D. Allen eds. Academic Press, New York): 237-255.

HanNig K., Kowalski M., Klock G., ZimmermanN U., MANG V. 1990. Free-flow electrophoresis under microgravity: evidence for enhanced resolution of cell separation. Electrophoresis 11: $600-604$.

HARRIS A. K. 1973. Cell surface movements related to cell locomotion. Ciba Found. Symp. 14: 3-26.

Hasslen S. R., Burns A. R., Simon S. I., SMith C. W., StARR K., BARClay A. N., Michie S. A., NELsON R. D., ERLANDSEN S. L. 1996. Preservation of spatial organization and antigenicity of leukocyte surface molecules by aldehyde fixation: flow cytometry and high-resolution FESEM studies of CD62L, CD11b, and Thy-1. J. Histochem. Cytochem. 44: 1115-1122.

Hausmann E., Stockem W. 1972. Pinocytose und Bewegung von Amoeben.VIII Mittelung: Endocytose und intracellulare Verdauung bei Hyalodiscus simplex. Cytobiologie 5: 282-300.

HaUsmann E., Stockem W., Wohlfarth-BotTermanN K. E. 1972. Pinocytose und Bewegung von Amoeben. VII Mittelung: Quantitative Untersuchungen zum Membran-Turnover bei Hyalodiscus simplex. Z. Zellforsch. 127: 234.

INGBER D. E. 2003. Tensegrity II. How structural networks influence cellular information processing networks. J. Cell Sci. 116: 1397-1408.

INGBER D. E., FOLKMAN J. 1989. Tension and compression as basic determinants of cell form and function: utilization of a cellular tensegrity mechanism. (In: Cell Shape: Determinants, Regulation and Regulatory Role. W. Stein, F. Bronner eds. Orlando, Academic Press): 1-32.

Jacobelli J., Chmura S. A., BuXTOn D. B., DAvis M. M., KRUMMEL M. F. 2004. A single class II myosin modulates T cell motility and stopping, but not synapse formation. Nat. Immunol. 5: 531-538.

JOHANSSON B., WyMANn M. P., HOLMGREN-PETERSON K., MAGNUSSON K. E. 1993. N-formyl peptide receptors in human neutrophils display distinct membrane distribution and lateral mobility when labeled with agonist and antagonist. J. Cell. Biol. 121: 1281-1289.

JOUNG J. J., AKIN C., ROYER G. P. 1987. Immobilization of growing cells by polyethyleneimine-modified alginate. Appl. Biochem. Biotechnol. 14: 259-275.

Jovtchev S., DJENEV I., STOEFF S., Stoylov S. 2000. Role of electrical and mechanical properties of red blood cells for 
their aggregation. Colloids and Surfaces A: Physicochemical and Engineering Aspects 164: 95-104

KELLER H. U. 2000. Redundancy of lamellipodia in locomoting Walker carcinosarcoma cells. Cell Motil. Cytoskeleton 46: 247-256.

Keller H., Rentsch P., HagmanN J. 2002. Differences in cortical actin structure and dynamics document that different types of blebs are formed by distinct mechanisms. Exp. Cell Res. 277: 161-172.

KELLER H. U., ZiMMERMANN A. 1985. Orthokinetic and klinokinetic responses of human polymorphonuclear leucocytes. Cell Motil. 5: 447-461.

Keller H. U., ZimmERMANN A. 1986. Shape changes and chemokinesis of Walker 256 carcinosarcoma cells in response to colchicine, vinblastine, nocodazole and taxol. Invasion Metastasis 6: 33-43.

Keller H. U., ZimmermanN A., Niggli V. 1989. Diacylglycerols and the protein kinase inhibitor H-7 suppress cell polarity and locomotion of Walker 256 carcinosarcoma cells. Int. J. Cancer 44: 934-939.

Kesbeke F., VAn HaAstert P. J. M., DE Wit R. J. W., SNAAR-JAGALSKA B. E. 1990. Chemotaxis to cyclic AMP and folic acid is mediated by different $G$ proteins in Dictyostelium discoideum. J. Cell Sci. 96: 669-673.

KOROHODA W. 1972 Some aspects of the interrelation among cell locomotion, contact phenomena, and cellular multiplication. Acta Protozool. 11: 161-172.

KorOHODA W., GOLDA J., SROKA J., WojNAROWICZ A. JOCHYM P., MADEJA Z. 1997. Chemotaxis of Amoeba proteus in the developing $\mathrm{pH}$ gradient within a pocket-like chamber studied with the computer assisted method. Cell Motil. Cytoskeleton 38: 38-53.

Korohoda W., MadeJA Z., SROKA J. 2002. Diverse chemotactic responses of Dictyostelium discoideum amoebae in the developing (temporal) and stationary (spatial) concentration gradients of folic acid, cAMP, $\mathrm{Ca}\left({ }^{2+}\right)$ and $\mathrm{Mg}\left({ }^{2+}\right)$. Cell Motil. Cytoskeleton 53: 1-25

KRISHNAN J., IGLESIAS P. A. 2004. A modeling framework describing the enzyme regulation of membrane lipids underlying gradient perception in Dictyostelium cells. J. Theor. Biol. 229: 85-99.

LASAROW R. M., Isseroff R. R., GOMEZ E. C. 1992. Quantitative in vitro assessment of phototoxicity by a fibroblast-neutral red assay. J. Invest. Dermatol. 98: 725-729.

Malawista S. E., DE Boisfleury Chevance A. 1997. Random locomotion and chemotaxis of human blood polymorphonuclear leukocytes (PMN) in the presence of EDTA: PMN in close quarters require neither leukocyte integrins nor external divalent cations. Proc. Natl. Acad. Sci. USA 94: 11577-11582.

Malawista S. E., DE Boisfleury CheVance A., BoXer L.A. 2000. Random locomotion and chemotaxis of human blood polymorphonuclear leukocytes from a patient with leukocyte adhesion deficiency-1: normal displacement in close quarters via chimneying. Cell Motil. Cytoskeleton 46: 183-189.

Malawista S. E., DE Boisfleury Chevance A., Brown E. J., BOXER L. A., LAW S. K. 2003. Chemotaxis of non-compressed blood polymorphonuclear leukocytes from an adolescent with severe leukocyte adhesion deficiency. Am. J. Hematol. 73: 115-120.

Malawista S. E., Van Damme J., SMallwoOd J. I., DE BOISFLEURY CHEVANCE A. 2002. Chemotactic activity of human blood leukocytes in plasma treated with EDTA: chemoattraction of neutrophils about monocytes is mediated by the generation of NAP-2. J. Leukoc. Biol. 72: 175-182.

Milne J. L., Coukell M. B. 1991. A Ca ${ }^{2+}$ transport system associated with the plasma membrane of Dictyostelium discoideum is activated by different chemoattractant receptors. J. Cell Biol. 112: 103-110.

MONTGOMERY R. R., LUSITANI D., DE BOISFLEURY CHEVANCE A., MALAWISTA S. E. 2004. Tick saliva reduces adherence and area of human neutrophils. Infect. Immun. 72: 2989-2994.
NEBL T., FisheR P. R. 1997. Intracellular $\mathrm{Ca}^{2+}$ signals in Dictyostelium chemotaxis are mediated exclusively by $\mathrm{Ca}^{2+}$ influx. J. Cell Sci. 110: 2845-2853.

PANTIN C. F. A. 1924. On the physiology of amoeboid movement. II. Brit. J. Exp. Biol. 1: 519-538.

Pomorski P., Watson J. M., Haskill S., Jacobson K. A. 2004. How adhesion, migration, and cytoplasmic calcium transients influence interleukin-1beta mRNA stabilization in human monocytes. Cell Motil. Cytoskeleton 57: 143-157.

Prigozhina N. L., WATERMAN-STORER C. M. 2004. Protein kinase D-mediated anterograde membrane trafficking is required for fibroblast motility. Curr. Biol. 14: 88-98.

PrZESTAlski S., KuCZERA J., GREGORCZYK C., MAZGis B. SARAPUK J., IDZIOR J. 1978. Permeation of phosphate ions cross membranes modifies by glutaraldehyde and osmium tetroxide. Studia Biophysica 69: 77-78.

REICHMAN-FrIED M., MININA S., RAZ E. 2004 Autonomous modes of behavior in primordial germ cell migration. Dev. Cell. 6: 589-596.

REYMOND C. D., SchaAP P., VERON M., Williams J.G. 1995. Dual role of cAMP during Dictyostelium development. Experientia 51: 1166-1174.

Sallusto F., Schaerli P., Loetscher P., Schaniel C., LENIG D., MACKAY C. R., QIN S., LANZAVECCHIA A. 1998. Rapid and coordinated switch in chemokine receptor expression during dendritic cell maturation. Eur. J. Immunol. 28: 2760-2769.

SAYERS Z., ROBERTS A. M., BANNISTER L. H. 1979 Random walk analysis of movement and galvanotaxis of Amoeba proteus. Acta Protozool. 18: 313-325.

SEAMAN G. V. F., COOK G. M. W. 1965. Modification of electrophoretic behaviour of the erythrocyte by chemical and enzymatic methods. (In: Cell Electrophoresis. E. J. Ambrose, J. A. Churchill Ltd. eds, London): 48-65.

Servant G., Weiner O. D., Neptune E. R., Sedat J. W. BOURNE H. R. 1999. Dynamics of a chemoattractant receptor in living neutrophils during chemotaxis. Mol. Biol. Cell. 10: 1163-1178.

Sroka J., Madeja Z., Michalik M., Przestalski S KOROHODA W. 2002. Folic acid, ascorbic acid and sodium selenite restore the motility of Dictyostelium discoideum inhibited by triethyllead. Toxicology 180: 275-292.

STOCKEM W. 1972. Membrane turn-over during locomotion of Amoeba proteus. Acta Protozool. 11: 83-93.

SZYDEOWSKA H., ZAPOROWSKA E., KUSZLIK-JOCHYM K., KOROHODA W., BRANNY J. 1978. Membranolytic activity of detergents as studied with cell viability tests. Folia Histochem. Cytochem. 16: 69-78.

TAmagnone L., Comoglio P. M. 2004. To move or not to move? Semaphorin signalling in cell migration. EMBO Rep. 5: 356-361

TANAKA Y., ITAKURA R., AMAgAi A., MAEDA Y. 1998. The signals for starvation response are transduced through elevated $\left[\mathrm{Ca}^{2+}\right]$ in Dictyostelium cells. Exp. Cell Res. 240: 340-348.

Tillinghast H. S., Newell P. C. 1987. Chemotaxis towards pteridines during development of Dictyostelium. J. Cell Sci. 87: 45-53.

VON TScharner Bitno N., PorZig H., Keller H. 1997. Suppression of polarity, locomotion and F-actin levels of Walker carcinosarcoma cells by the inhibitor CI-959. Life Sci. 61: 137-145.

VAN HaAstert P. J., KiEn E. 1983. Binding of cAMP derivatives to Dictyostelium discoideum cells. Activation mechanism of the cell surface cAMP receptor. J. Biol. Chem. 258: 9636-9642.

WALIGÓRSKA A., WiANECKA-SKOCZEŃ M., NOWAK P. KOROHODA W. 2007. Some difficulties in research into cell motile activity under isotropic conditions. Folia biol. (Kraków) 55: 9-16.

WILKINSON P. C. 1987. Leucocyte locomotion: behavioural mechanisms for accumulation. J. Cell Sci., Suppl. 8: 103-119. 
WÓJCIAK-STOTHARD B., DENYER M., MiSHRA M., BROWN R. A. 1997. Adhesion, orientation, and movement of cells cultured on ultrathin fibronectin fibers. In Vitro Cell Dev. Biol. Anim. 33: 110-117.

ZiMMERMANN A., KELLER H. 1992. Effects of staurosporine, $\mathrm{K} 252 \mathrm{a}$ and other structurally related protein kinase inhibitors on shape and locomotion of Walker carcinosarcoma cells. Br. J. Cancer 66: 1077-1082.

ZimMERMANN A., KELleR H. 1993. Shape changes and chemokinesis of Walker carcinosarcoma cells: effects of protein kinase inhibitors (HA-1004, polymyxin B, sangivamycin and tamoxifen) and an inhibitor of diacylglycerol kinase ( $\mathrm{R}$ 59022). Anticancer Res. 13: 347-354. 